\title{
LANDSCAPE EVALUATION OF MOSQUE GARDEN BASED ON THE CONCEPT OF ISLAM
}

Received January 6th, 2020 | Accepted April 13th, 2020 | Available online December 15th, 2020

| DOI http://dx. doi. org/10.18860/jia.v6i2.8028 |

\section{ISNAENI NUR TAFLIHA}

IPB University

Indonesia

isnaeninur.tafliha@gmail.com

\begin{abstract}
Islam is a religion that has a comprehensive concept. It regulates everything in the Muslim's life because everything is connected with Islam, including designing a garden. This paper discusses the textual concept of the garden in Islam based on the Al-Quran and al-Hadith as the two primary sources in Islam. The textual analysis aims to formulate garden design criteria based on the concept of Islam. The design criteria were then used to evaluate the mosque's landscape by studying perceptions and user preferences. The two selected mosque locations are the Istiqlal Mosque and the Jakarta Islamic Center Mosque. The method applied in this study is a literature study and the distribution of questionnaires. The paper's results and discussion are divided into three parts: 1) garden design criteria based on the Al-Quran and al-Hadith; 2) some sharia limitations in designing the garden; 3) evaluation on two research locations through the study of perceptions of mosque garden users.
\end{abstract}

KEYWORDS: AI Quran; al-Hadith; Islam; landscape evaluation; mosque

\section{INTRODUCTION}

As a comprehensive (syumuliyyah) religion, Islam has the quality of being universal, that it has both vertical (worship of mahdhah) and horizontal (worship of muamalah) correlation. Matters concerning muamalah are quite general, which within it includes the conception of building a garden. Al-Quran and al-Hadith can be referred to as the concept's reference for building the garden through the values approach contained inside them [1]. The main consent in planning, designing, and managing the garden is not restricted to spaces, shapes, patterns, or elements, but more of the garden's functional aspect that does not contradict Islamic thought [2].

The depiction of paradise's garden is one source of inspiration in al-Quran and al-Hadith for the garden to be built [3]. Allah Swt describes heaven as something that is still imaginable by human capacity, even though heaven's reality, what will be seen and witnessed related to its pleasure, might be manifold better than what was conveyed in the Quran al-Hadith [4]. The paradise garden concept itself can be interpreted as a narrative approach that is an approach that associate Islamic teaching with a garden's design [5]. This elaboration shows that a study about the garden's design can be developed by searching for al Quran and al Hadith's contents as an inspiration source of problems regarding muamalah.
The mosque acts as a center for Islamic activities with positive social environmental values of Muslims [6], partly because of the garden's existence as part of the mosque complex. The garden's presence and function may be related to the mosque class's status determined by the Indonesian Mosque Council. Nevertheless, the powerful concept of Islamic activities in a mosque may also be a reference point for developing a mosque's landscape, regardless of its class status.

This study aims to analyze and formulate Islamic garden design criteria based on the Al-Quran and alHadith content. Furthermore, the formulation results are processed into an evaluation tool to determine the extent of its implementation in garden design in Indonesia. The mosque garden was chosen as the study's location because it considers its function to support the mosque as a center for Muslim activities. In this study, the two mosques are the Istiqlal Mosque as the state mosque and the Jakarta Islamic Center Grand Mosque as the grand mosque (provincial scale) [7]. Both locations were chosen by taking into account the mosque's two statuses, so it is assumed that many functions and activities occur in the mosque complex.

The evaluation is completed through the study of the respondent's perceptions. The perception of garden users and visitors can show the functions and space experiences [8]. The results of the perception study can become a tool to evaluate the garden's design's success. 


\section{METHODS}

The data collection phase began with a literature study method which included 1) the formulation of garden design criteria concerning the depiction of heaven in the al-Quran and al-Hadith, and 2) sharia limitations that must be considered in garden design. There are three main references used at this stage:

Al Quran as the primary source of law in Islam along with two types of interpretation, namely Tafsir Jalalain and Tafsir Ibn Kathir;

Six popular al-Hadith books, namely Sahih Bukhari, Sahih Muslim, Sunan At-Tirmidhi, Sunan Abu Dawud, Sunan An Nasa'i, and Sunan Ibn Majah;

Another scientific literature.

Searching for al Quran verses also uses several tools, including Ayat software by King Saud University (2015) and the online site https://tafsir.learn-quran.co/ id. Meanwhile, tracing al Hadith's books is accessed by the Ensiklopedi Hadits 9 Imam software by Lidwa (2018).

Data analysis was done descriptively through a literature study. Data from the search results of the alQuran and al-Hadith's verses about heaven's depiction, then identified, selected, and grouped based on indicators of garden element and garden character. The grouping results are then analyzed by referring to scientific literature that supports to obtain garden design criteria based on the content of the al- Quran and al-
Hadith. The analysis of sharia boundaries in garden design was developed based on indicators formulating the implications of existing Islamic rules for designing a garden.

The field survey and observation methods were carried out to obtain information about the garden's quality in each mosque and how intensive people were using it. Retrieval of perception data is completed by interviewing the respondent directly by answering the questionnaire. In this study, the respondents were 60 people in each mosque, so 120 respondents were obtained. The sampling technique uses accidental sampling, where respondents who incidentally meet with researchers can be used as samples [9].

The question variables were developed based on the formulation of the garden design criteria based on the al-Quran and al-Hadith's content and the requirements for sharia restrictions. The questionnaire consisted of the following sections: (1) respondent profile; (2) perception of the function of the mosque garden; (3) perception of the implementation of sharia restrictions in the mosque garden; and (4) perception of the quality of the mosque garden design. Measurement of perception using a Likert scale with a range values of $1-5$. The data is processed descriptively in tabular form for the types of informative questions and then conducted a linear regression analysis of Likert scale questions.

Table 2. The element's criteria, according to Al-Quran and al-Hadith.

\begin{tabular}{|c|c|c|c|c|c|}
\hline \multirow[t]{2}{*}{ No. } & \multirow{2}{*}{$\begin{array}{l}\text { Garden } \\
\text { element }\end{array}$} & \multirow[t]{2}{*}{ Description of element inside Al Quran and/or al-Hadith } & \multicolumn{2}{|c|}{ Number of findings } & \multirow[t]{2}{*}{ Application on the garden } \\
\hline & & & Al Quran & Al Hadith & \\
\hline 1. & $\begin{array}{l}\text { The function of } \\
\text { the water } \\
\text { element }\end{array}$ & $\begin{array}{l}\text { The garden of heaven is described as a garden with its } \\
\text { rivers flowing with various enjoyment of its inhabitants } \\
\text { (QS 47:15). }\end{array}$ & 52 & 51 & $\begin{array}{l}\text { Exploring the water element to provide } \\
\text { various garden functions, such as aesthet- } \\
\text { ics, psychology, or physical. }\end{array}$ \\
\hline 2. & $\begin{array}{l}\text { The visualiza- } \\
\text { tion of the } \\
\text { water element }\end{array}$ & $\begin{array}{l}\text { Rivers in the garden of heaven are described as always } \\
\text { flowing (QS 13:35) and having a beauty perfect, like the } \\
\text { edges, which are made of gold (HR Tirmidzi No. 3284). }\end{array}$ & 52 & 51 & $\begin{array}{l}\text { Creative and exciting visualization of } \\
\text { water elements is the dynamics, reflection, } \\
\text { and merging with art elements. }\end{array}$ \\
\hline 3. & Type of plant & $\begin{array}{l}\text { Garden of heaven provides enjoyment of various types } \\
\text { of fruits (HR Ibnu Majah No. 1255) by the amount of a lot } \\
\text { (QS 56:32). }\end{array}$ & 21 & 16 & $\begin{array}{l}\text { Diversity of plant types including to con- } \\
\text { sider productive plants that can be har- } \\
\text { vested. }\end{array}$ \\
\hline 4. & $\begin{array}{l}\text { Function and } \\
\text { location of the } \\
\text { garden }\end{array}$ & $\begin{array}{l}\text { The shade of trees that never stop (QS 13:35) and its } \\
\text { perfect beauty, like its branches made of gold (HR Tirmi- } \\
\text { dzi No. 2448). }\end{array}$ & 6 & 12 & $\begin{array}{l}\text { Suitability of the plant's function and } \\
\text { location in a garden, including structural } \\
\text { function, environmental, and visual. }\end{array}$ \\
\hline 5. & Garden's safety & $\begin{array}{l}\text { Allah SWT. perfect the plants in heaven including its } \\
\text { safety, like a thorny tree which is not thorny (QS } 56: 28)\end{array}$ & 2 & - & $\begin{array}{l}\text { Selection of the right type of plant and } \\
\text { considering the level of its safety. }\end{array}$ \\
\hline 6. & Biodiversity & $\begin{array}{l}\text { In the garden of heaven, there are green birds perched } \\
\text { on the trees that carry the spirit of the syuhada (HR } \\
\text { Tirmidzi No 1565) }\end{array}$ & - & 10 & $\begin{array}{l}\text { Biodiversity of a garden that supports } \\
\text { animal life. }\end{array}$ \\
\hline 7. & Accessibility & $\begin{array}{l}\text { The gates of heaven are always guarded (Qur'an 13:23), } \\
\text { and its names are distinguished according to the kind of } \\
\text { good deeds done by a human (HR Bukhari No. 1764). }\end{array}$ & 3 & 67 & $\begin{array}{l}\text { The garden's door is legible and has a } \\
\text { security system. }\end{array}$ \\
\hline 8. & $\begin{array}{l}\text { The function of } \\
\text { the garden's } \\
\text { building }\end{array}$ & $\begin{array}{l}\text { Allah SWT provides magnificent buildings (QS 29:58) as a } \\
\text { resting place good (HR Bukhari No. 622). }\end{array}$ & 17 & 86 & $\begin{array}{l}\text { Buildings inside the garden (both major } \\
\text { and minor) are used as a place for resting } \\
\text { and shelter, and the vocal points a garden. }\end{array}$ \\
\hline 9. & $\begin{array}{l}\text { Completeness } \\
\text { of the site } \\
\text { furniture }\end{array}$ & $\begin{array}{l}\text { Allah SWT. Provide a variety of beautiful furniture in the } \\
\text { garden of heaven, like a laver made of gold (Muslim HR } \\
\text { No. 5065). }\end{array}$ & 20 & 18 & $\begin{array}{l}\text { Garden's furniture (or site furniture) can } \\
\text { fulfill many functions by permanently pay } \\
\text { attention to explore its artistic value. }\end{array}$ \\
\hline 10. & Colors & $\begin{array}{l}\text { The garden's representation is very green and beautiful } \\
\text { (HR Bukhari No. 3529) with pristine flowing water (QS } \\
\text { 37:46). }\end{array}$ & 7 & 39 & $\begin{array}{l}\text { The creative combination of the color is } \\
\text { not monotonous, so it emphasizes its } \\
\text { natural impression. }\end{array}$ \\
\hline 11. & Noise & $\begin{array}{l}\text { The garden of heaven is described as a quiet place (HR } \\
\text { Muslim No. 4460), and there are only decent noises } \\
\text { (Qur'an 19:62). }\end{array}$ & 7 & 15 & $\begin{array}{l}\text { Providing the garden with natural sounds } \\
\text { has a positive impact while controlling the } \\
\text { loud noises of external causes. }\end{array}$ \\
\hline 12. & Scent & $\begin{array}{l}\text { Garden of heaven has a fragrant scent like a musk (QS } \\
\text { 83:26) and scent soil from adzfar oil (HR Bukhari No. } \\
6095) \text {. }\end{array}$ & 1 & 32 & $\begin{array}{l}\text { Providing natural scents by planting flow- } \\
\text { ery plants to fight unsavory odor }\end{array}$ \\
\hline
\end{tabular}

113 | Journal of Islamic Architecture, 6[2] December 2020 


\section{DISCUSSION}

\section{THE GARDEN DESIGN CRITERIA BASED ON THE CONTENT OF} THE AL QURAN AND AL HADITH

Islam is very partial, justifies, and even permits the presence of art and beauty, along with the behavior of enjoying and appreciating it [10]. Creativity is permissible in Islam as long as it aims for good, one of which carries out human duties as Khalifah. Allah SWT describes heaven through various verses in the al Quran and the Prophet, through several al-Hadith that can be used to reference the garden concept. However, it will not be comparable to the pleasure of heaven in the hereafter. The following are the results of searching the verses of the al-Quran and al-Hadith that can be used to reference the park concept (Table 1).
Table 1. Search result of the verses of Al-Quran and Al-Hadith about the garden of heaven

\begin{tabular}{|c|c|c|c|c|c|c|c|}
\hline Indicator $^{1}$ & A & $\overline{B 1}$ & B2 & B3 & B4 & B5 & B6 \\
\hline \multicolumn{8}{|l|}{ 1. Garden element } \\
\hline 1.1 Soft element & 76 & 21 & 23 & 27 & 7 & 8 & 11 \\
\hline 1.2 Hard element & 40 & 37 & 31 & 27 & 42 & 10 & 23 \\
\hline 1.3 Design element & 15 & 22 & 17 & 20 & - & 8 & 19 \\
\hline \multicolumn{8}{|l|}{ 2. Garden character } \\
\hline 2.1 Physical character & 22 & 21 & 28 & 24 & 2 & 7 & 7 \\
\hline 2.2 Nonphysical character & 21 & 5 & 5 & 6 & 2 & - & 2 \\
\hline 2.3 User character & 122 & 28 & 20 & 30 & 4 & 7 & 9 \\
\hline
\end{tabular}

Table 3. The character's criteria, according to Al-Quran and al-Hadith.

\begin{tabular}{|c|c|c|c|c|c|}
\hline \multirow[t]{2}{*}{ No. } & \multirow[t]{2}{*}{ Character } & \multirow{2}{*}{$\begin{array}{l}\text { Description of character inside Al-Quran and/ } \\
\text { or al-Hadith }\end{array}$} & \multicolumn{2}{|c|}{ Number of findings } & \multirow[t]{2}{*}{ Application on the garden } \\
\hline & & & Al Quran & Al Hadith & \\
\hline 1. & Beauty & $\begin{array}{l}\text { Allah SWT creating a garden of heaven } \\
\text { as the most beautiful residence (QS 25:24), } \\
\text { even humans will be stunned seeing it (HR } \\
\text { Bukhari No. 6525). }\end{array}$ & 3 & 25 & $\begin{array}{l}\text { A Garden is a place for humans to interact with } \\
\text { nature, which provides immediate natural } \\
\text { beauty benefits. }\end{array}$ \\
\hline 2. & $\begin{array}{l}\text { Comfort } \\
\text { tempera- } \\
\text { ture }\end{array}$ & $\begin{array}{l}\text { Garden of heaven is a leafy and comfortable } \\
\text { place (QS 4:57), and its inhabitants won't be } \\
\text { feeling any sweltering heat because of its } \\
\text { shade (QS 76:14). }\end{array}$ & 7 & 16 & $\begin{array}{l}\text { The garden provides a comfortable tempera- } \\
\text { ture (cool) and physiological (cool) for its } \\
\text { users. }\end{array}$ \\
\hline 3. & Area & $\begin{array}{l}\text { Allah SWT creating a garden of heaven as an } \\
\text { extensive park (HR Muslim No. 4536) as wide } \\
\text { as the sky and earth (QS } 3: 133 \text { ) }\end{array}$ & 3 & 22 & $\begin{array}{l}\text { The park area is determined according to its } \\
\text { function and user activities, including giving } \\
\text { the freedom to choose the type of space need- } \\
\text { ed. }\end{array}$ \\
\hline 4. & $\begin{array}{l}\text { Ease of } \\
\text { access }\end{array}$ & $\begin{array}{l}\text { Allah SWT guarantees all forms of conven- } \\
\text { ience for the heaven inhabitants, as it is } \\
\text { brought near to the pious people (HR Muslim } \\
\text { No. 288) and the comfort to get fruits in } \\
\text { there (QS 55:54). }\end{array}$ & 9 & 4 & $\begin{array}{l}\text { There is easy access (location and entry) for its } \\
\text { users, including universal garden design } \\
\text { (equitable). }\end{array}$ \\
\hline 5. & $\begin{array}{l}\text { Shared } \\
\text { space }\end{array}$ & $\begin{array}{l}\text { Allah SWT bring together residents of heav- } \\
\text { en to enter together (Qur'an 13:23), as it is } \\
\text { the troupe with that face radiating light (HR } \\
\text { Bukhari No. 6060). }\end{array}$ & 7 & 26 & $\begin{array}{l}\text { A garden can accommodate users to move } \\
\text { together, interact socially, and improve rela- } \\
\text { tions between the community. }\end{array}$ \\
\hline 6. & Security & $\begin{array}{l}\text { Allah SWT guarantees security inhabitants of } \\
\text { heaven, that is, a state of security from all } \\
\text { torments, safe from feeling afraid, and safe } \\
\text { from distractions from all terrible crimes } \\
\text { (Qur'an 34:37). }\end{array}$ & 5 & - & $\begin{array}{l}\text { For a garden to be environmentally friendly } \\
\text { and safe, it needs a security system, monitor- } \\
\text { ing, and good management. }\end{array}$ \\
\hline 7. & $\begin{array}{l}\text { Recrea- } \\
\text { tion }\end{array}$ & $\begin{array}{l}\text { The garden of heaven is a reward that Allah } \\
\text { Swt gives His servant (Qur'an 32:19), and its } \\
\text { inhabitants will feel satisfied with it (QS } \\
\text { 32:19). }\end{array}$ & 20 & 14 & $\begin{array}{l}\text { Parks is a recreational place that can entertain } \\
\text { and refresh the mind from a tiring routine. }\end{array}$ \\
\hline 8. & $\begin{array}{l}\text { User's } \\
\text { behavior }\end{array}$ & $\begin{array}{l}\text { Garden of heaven is a place for believers (HR } \\
\text { Muslim No. 81), do good (QS 5:85), and be } \\
\text { devoted (Qur'an 3:15). }\end{array}$ & 71 & 41 & $\begin{array}{l}\text { The garden users' positive behavior creates a } \\
\text { conducive garden situation and can direct its } \\
\text { users to do good things. }\end{array}$ \\
\hline 9. & $\begin{array}{l}\text { User's } \\
\text { feeling }\end{array}$ & $\begin{array}{l}\text { Garden of heaven is described as a place full } \\
\text { of pleasure (QS 31: 8) and filled with excite- } \\
\text { ment for its inhabitants (HR Bukhari No. } \\
764) \text {. }\end{array}$ & 24 & 37 & $\begin{array}{l}\text { A garden is comfortable enough to provide a } \\
\text { positive effect on the user's psychology. }\end{array}$ \\
\hline 10. & $\begin{array}{l}\text { Type of } \\
\text { activity }\end{array}$ & $\begin{array}{l}\text { Garden of heaven is the best resting place, a } \\
\text { place for the residents to do some activities } \\
\text { such as sitting around (QS 15:47), lying down } \\
\text { (QS 36:56), drink (QS 77:43), and eat (QS } \\
\text { 77:43). }\end{array}$ & 27 & 30 & $\begin{array}{l}\text { The park is the place to do activities that posi- } \\
\text { tively impact the users' physical, mental, and } \\
\text { spiritual. }\end{array}$ \\
\hline
\end{tabular}

The results in Table 1 are obtained based on the description of the translation of the Al Quran verses and selected al-Hadith based on 1) a description of water, plants, and animals which are grouped into soft elements; 2) a description of the door, the building, and some furniture in the garden of heaven which is grouped into hard elements; and 3) descriptions of colors, aromas, and sounds in the garden of paradise which is grouped into design elements. The characters of the garden are selected based on 1) description of beauty, shade, area, shared space, and easy access, which is grouped into physical characters; 2 ) a descrip- 
tion of a recreational and safe character of the garden grouped into non-physical characters; and 3) a description of how the inhabitants of heaven and the activities in it are grouped into user characters. Furthermore, the grouping results were analyzed using related scientific references to obtain some garden elements mentioned in heaven (Table 2), and some garden characters (Table 3) applied to garden designs.

Table 4. Limitation criteria of sharia on the garden

\begin{tabular}{|c|c|c|c|}
\hline No. & & ation criteria of sharia ${ }^{1}$ & Description and application to the garden design \\
\hline \multirow[t]{2}{*}{1.} & $\begin{array}{l}\text { Garden } \\
\text { element }\end{array}$ & $\begin{array}{c}\text { Its shape does not resemble } \\
\text { animals and humans }\end{array}$ & $\begin{array}{l}\text { The sculpture is a common element in a park garden. Hilmi [11], through the Al Quran Surah } \\
\text { Az Zumar verse } 3 \text { (QS 39: 3), explains that forbidding the statue in Islam is a gesture of } \\
\text { caution because it can be intermediary shirk and glorification over something. There are } \\
\text { several differences between scholars in addressing this problem. However, one of the } \\
\text { lightening ones is, it was agreed for the permissibility of statues as children's toys with the } \\
\text { conditions: the shape is not perfect to resemble animals and humans; has an exact function } \\
\text { for example as a means of da'wah, education, or game; and does not show genitals [11]. }\end{array}$ \\
\hline & & $\begin{array}{l}\text { It does not use materials like } \\
\text { gold or silver }\end{array}$ & $\begin{array}{l}\text { Islam specifically forbids gold and silver as furniture because they contain excessive ele- } \\
\text { ments (israf) [12]. Related to the garden aspects, the selection of gold and silver material is } \\
\text { less efficient because it will require intensive care. The garden's character's material should } \\
\text { be easy to care for and durable, so it simplifies the maintenance process [13]. }\end{array}$ \\
\hline \multirow[t]{2}{*}{2.} & $\begin{array}{l}\text { Garden } \\
\text { character }\end{array}$ & It does not deny sunnatullah & $\begin{array}{l}\text { Ar-Rifa'i [14] through Surah Fathir verse } 43 \text { (QS 39:43) explains that sunnatullah is essential- } \\
\text { ly a natural law, so things that are not in accordance with it can be categorized as actions of } \\
\text { exploiting too much, even tend to damage nature. Allah SWT assigning humans as khalifa } \\
\text { so that in cultivating nature, including building a garden, must pay attention to environ- } \\
\text { mental balance. }\end{array}$ \\
\hline & & It does not exaggerate & $\begin{array}{l}\text { Sarwat [12], through Surah Al Isra 'verse } 27 \text { (QS 17:27), explains that excessive or wasteful } \\
\text { actions are prohibited in Islam. Therefore, the garden's design must be functional, so there } \\
\text { are no spaces, elements, facilities that are not used optimally. }\end{array}$ \\
\hline 3. & $\begin{array}{l}\text { Activities } \\
\text { inside the } \\
\text { garden }\end{array}$ & $\begin{array}{l}\text { Not doing any activities that } \\
\text { are contrary to Islamic teach- } \\
\text { ings }\end{array}$ & $\begin{array}{l}\text { Ash'ari [15], through Surah An-Nisa verse } 36 \text { (QS 4:36), explains that Islam's essence is mon- } \\
\text { otheism, so things are closer to shirk, especially its actions are strictly prohibited. Related } \\
\text { with activities inside the garden, Islam does not prohibit social activities with local cultural } \\
\text { values as long as it does not conflict with faith [16]. Supervision of garden users' activities } \\
\text { needs to be carried out to maintain mutual safety and comfort [13]. Any actions that dam- } \\
\text { age the facility garden (vandalism), including behavior that pollutes the garden (QS 2:11), is } \\
\text { an example of an activity that can cause discomfort. Social interaction is also considered in } \\
\text { Islam's teachings, ikhtilat, namely the mixing of men and women in joint activities, with no } \\
\text { boundaries separating the two. The limits that must be considered are how the activity } \\
\text { does not approach adultery (QS 17:23) and is not contradictory to society's social norms. }\end{array}$ \\
\hline
\end{tabular}

Note: ${ }^{1}$ Indicator by [2]

\section{LIMITATION CRITERIA OF SHARIA}

Qardhawi through Surah al-Baqarah verse 104 (QS 2: 104) explains that the first basis established in Islam regarding muamalah is about the halal and changing things that were created by Allah [17]. Nothing is forbidden, except because it is explicit (the authorized who make the law itself, that is Allah Swt. and the Messenger of Allah.) that bans it. The forbidden things in Islamic sharia are very narrow, and the ignited things are very broad [17]. The only reason as to why Allah Swt. Forbids something because it can bring harm to humans.

The al Quran introduces Islam through Surah ar Rum verse 30 (QS 30:30) as a following human nature [18]. Art, including human creativity in building a garden, is part of humans who love beauty. Islam sees the park as part of the human nature of being neutral (mubah) to become a means to achieve goodness [15]. Therefore, sharia boundaries in garden design need to be known so that they do not conflict with Islamic values [18] and do not lead to more inconsistency [2]. Some constraints in sharia and how they are applied in the garden design are explained in Table 4.

\section{EVALUATION IN ACCORDANCE OF THE USER'S PERCEPTION}

Istiqlal Mosque is a state mosque that functions as a center of Islamic activities on a national scale. The area of the Istiqlal Mosque is 9.3 ha with a proportion of space built compared to open space by $24 \%: 76 \%$. Jakarta Islamic Grand Mosque Center (JIC) is a grand mosque (provincial scale), development and Islamic culture, and a central economics study. JIC land area is 10.9 ha with the proportion of space built compared to the open space of $44 \%: 56 \%$. The outdoor space at both mosques functions as facilities to support Islamic activities that takes place there, such as the green open spaces, parking areas, and circulation paths.

Respondents of gender male sex dominate respondents' characteristics in Istiqlal Mosque by $56.67 \%$ and adult age categories (21-49 years) by $70 \%$. The majority of respondents who came from Jakarta's area is $49 \%$, and whose purpose was too religious tourism is $41.67 \%$. Respondents of gender female sex dominate respondents' characteristics in the JIC Grand Mosque by $61.67 \%$ and adult age categories (21-49 years) by $70 \%$. The majority of respondents settled in North Jakarta is $43.33 \%$ and came to carry out spiritual activities, such as routine study activities, and classes of da'wah's train- 
ing are $43.33 \%$.

Through perception evaluation, most of the respondents stated that mosque gardens play an essential role in supporting the mosque's function as a means of worship. It emerges from the average value obtained, i.e., 4.63 for the Istiqlal Mosque and 4.43 for the JIC Grand Mosque. A mosque is a communal space that can play a role to provide multifunctional space and satisfy the social needs of the community [6] Istiqlal Mosque respondents stated that the most beneficial factor of the mosque's activities was the mosque's garden, especially their supporting facilities such as a large parking area (33\%) and environmental benefits in the presence of green open space (27\%). Respondents of the JIC Grand Mosque stated mostly the same, the existence of the mosque garden facilitate many activities such as an area of expansion of worship activities, such as Eid Al-Fitr and Eid Al-Adha (31\%) and environmental benefits in the presence of large green open spaces (29\%).

The results of respondent's perceptions of the implementation of sharia's restrictions on the mosque garden show the mosque design does not use decoration, either in the form of statues or patterns illustrated with a shape resembling animals and humans. It is seen from a high average value, which is 4.73 for the Istiqlal Mosque and 4.90 for the JIC Grand Mosque (Table 5). Respondents assessed that aspects of environmental balance in the garden of the Istiqlal mosque are relatively low. It is allegedly due to the condition of the Ciliwung river in the region, which is sometimes found in dirty and smelly conditions. Limitation of sharia in prohibited activities at the JIC Grand Mosque obtains the lowest average grade. It is based on interview results with respondents that sometimes they found teenagers dating in the mosque environment.

\begin{tabular}{llcc}
\multicolumn{4}{c}{ Table 5. Respondent's perception of sharia } \\
\hline No. & $\begin{array}{c}\text { Limitation variable of } \\
\text { sharia }\end{array}$ & $\begin{array}{c}\text { Average value } \\
\text { Istiqlal } \\
\text { Mosque }\end{array}$ & $\begin{array}{c}\text { JIC } \\
\text { Grand } \\
\text { Mosque }\end{array}$ \\
\hline 1 & $\begin{array}{l}\text { Shapes resembling } \\
\text { animals and humans }\end{array}$ & 4,73 & 4,90 \\
\hline 2 & Functional & 3,53 & 3,70 \\
\hline 3 & $\begin{array}{l}\text { Pay attention to envi- } \\
\text { ronmental balance }\end{array}$ & 2,83 & 3,67 \\
\hline 4 & Prohibited activities & 3,03 & 3,23 \\
\hline
\end{tabular}

Islam gives its followers the freedom to be creative in making the garden by taking into account sharia's restrictions. The garden is built strictly in the corridors of Islamic teachings. A garden where the situation can direct its users into doing positive activities in the park can ultimately build socially positive relationships [13]. Related to the results of the respondent's perceptions, the management of the two mosques needs to be improved, especially associated with the physical management of the garden and supervision of its user activities. Aspect management was raised in the study because of garden manage- ment, specifically maintenance. Low maintenance can cause the state of the garden is not appropriate with the original design.

Perceptions of the quality of the garden's design are explained in Table 6. Questionnaires were divided into five groups of variables: the garden's accessibility, element, management, facilities, and social activities or functions. These variables are developed by referring to the criteria of the garden's element and character obtained.

Table 6. Respondent's perception of gardens design

\begin{tabular}{|c|c|c|c|}
\hline \multirow{2}{*}{ Variable } & \multicolumn{3}{|c|}{ Means } \\
\hline & A & & B \\
\hline Accessibility & Ease of location & 4,13 & 2,90 \\
\hline \multirow{4}{*}{$\begin{array}{l}\text { Garden's } \\
\text { element }\end{array}$} & Entry access & 4,00 & 4,26 \\
\hline & $\begin{array}{l}\text { The arrangement } \\
\text { and variety of } \\
\text { plants }\end{array}$ & 2,80 & 3,03 \\
\hline & Water element & 2,83 & 3,60 \\
\hline & $\begin{array}{l}\text { Green area (green } \\
\text { govenance func- } \\
\text { tion) }\end{array}$ & 3,23 & 3,57 \\
\hline \multirow{2}{*}{ Management } & Cleanliness & 2,93 & 2,97 \\
\hline & Security & 2,83 & 3,63 \\
\hline \multirow{4}{*}{$\begin{array}{l}\text { Garden's } \\
\text { facility }\end{array}$} & Area & 4,03 & 4,47 \\
\hline & Site furniture & 2,97 & 3,00 \\
\hline & Beauty & 3,10 & 4,13 \\
\hline & Convenience & 3,53 & 3,90 \\
\hline \multirow{3}{*}{ Activity } & Shared space & 3,97 & 4,27 \\
\hline & Recreation & 4,50 & 4,10 \\
\hline & Feeling effect & 3,37 & 4,10 \\
\hline
\end{tabular}

Note: $\mathrm{A}=$ Istiqlal Mosque; $\mathrm{B}=\mathrm{JIC}$ Grand Mosque

Istiqlal Mosque is one of the most popular destinations for religious tourism. It is evident from the respondents' perceptions that indicate the high value of recreation (Table 6). The mosque garden's role can be enhanced to support the Istiqlal Mosque's function to be appropriate with its primary function as a worship place. It is important to pay more attention to the implementation of Islamic principles so the tour activities do not interfere or reduce the mosque's spiritual value. As shown in Table 6, the variable of the garden's arrangement and variety of plants gave out low value. It may be caused by some areas of the mosque garden that are not managed optimally and select plant types with less varied colors. Al Quran in surah ar-Rahman verse 64 (QS 55:64) represents paradise's garden as very leafy as if the branches are fused. This verse can be used as inspiration to make a green and natural impression on the garden's design. A combination of various kinds of trees, shrubs, and flowers gives the impression of a more natural and visually attractive garden than monotonous ones [19].

Meanwhile, the JIC Grand Mosque respondent considers that the area of the park is very supportive of Islamic activities. Those can be seen in the garden's area variable value, which is high (Table 6). Inspiration about the garden area is also explained in the Al-Hadith 
by Bukhari No. 3529. That said, how heaven's garden is represented as exceptionally spacious with a green and beautiful atmosphere. The mosque garden area can also become an attractiveness that supports the mosque as a center of worship activities. Extensive gardens can provide space for social interaction and improve relations between communities [20].

Table 7. Linear regression test of Istiqal Mosque

\begin{tabular}{llll}
\hline Category & df & R-square & P-value \\
\hline Sharia limitation & 1 & 0,596 & 0,000 \\
\hline Activity & 1 & 0,302 & 0,002 \\
\hline Management & 1 & 0,232 & 0,007 \\
\hline Garden's element & 1 & 0,191 & 0,016 \\
\hline Garden's facility & 1 & 0,166 & 0,026 \\
\hline
\end{tabular}

The results of linear regression tests in both mosques (Tables 7 and 8) show sharia constraints has a role of $60 \%$ in the Istiqlal Mosque and $33 \%$ in the Greater JIC Mosque in determining the perception of the garden's role as a facility to support religious facilities. It shows a mosque garden that applies sharia restrictions in its design, and its management can support the creation of strong Islamic values. Variable of activity influences the respondent's perceptions of the Istiqlal Mosque garden's role by $30 \%$. The mosque garden can be an effective place for its users to be spending free time and do activities that can provide a positive experience for psychology [8]. Variable of the garden's element affect the respondent's perception of the JIC Masjid Raya garden's role by $27 \%$. This result is parallel with Payne's statement that natural scenes created through an exciting composition garden's element will provide comfort for its users [21].

\begin{tabular}{llcc}
\multicolumn{4}{c}{ Table 8. Linear regression test of JIC Grand Mosque } \\
\hline Category & df & R-square & P-value \\
\hline $\begin{array}{l}\text { Sharia } \\
\text { limitation }\end{array}$ & 1 & 0,328 & 0,001 \\
\hline Activity & 1 & 0,266 & 0,004 \\
\hline Management & 1 & 0,233 & 0,007 \\
\hline $\begin{array}{l}\text { Garden's } \\
\text { element }\end{array}$ & 1 & 0,183 & 0,018 \\
\hline $\begin{array}{l}\text { Garden's } \\
\text { facility }\end{array}$ & 1 & 0,13 & 0,022 \\
\hline
\end{tabular}

\section{CONCLUSION}

Based on the literature studies results, we obtained 12 design elements of the garden element based on 113 verses of the al-Quran and 276 al-Hadith that describe the garden of heaven and ten garden character design criteria based on 121 verses of the al Quran and 163 al-Hadith. Also, sharia limitation is realized as matters that must be considered in the garden's design not to contradict the values and teachings of Islam, including limitation of the shape and material of garden elements, the garden's character, and its user activities. The study of respondent's perceptions shows that the criteria for sharia's limitation positively affect the garden's role in supporting the function of the mosque as medium worship.

\section{REFERENCES}

[1] M. B. Tajudin and H.M. Rasdi, "Reconstructing the idea of Islamic architecture: restructuring the academic framework and design approach within the perspective of the Sunnah," Journal of Architecture, vol. 13, no. 3, pp. 297-315, 2008.

[2] M. Jannah, W. Q. Mugnisyah, and A. Gunawan, "Kajian konsep taman Islam berdasarkan Al Quran dan hadis', El-Harakah, vol. 17, no. 1, pp. 1-17, 2015.

[3] N. H. Hussain, K. Hassan, and N. Mt Akhir N. "Establishing the Malay Landscape Elements through Islamic Garden Perspective. $7^{\text {th }}$ Asian Conference on Environment-Behaviour Studies National Taiwan University; 2016 April 9-10; Taipei, Taiwan, Taipei (TW): E-BPJ, vol. 1, no. 3, pp. 183-192, 2016.

[4] A. Halim. Pesona Surga. Fajar K., translator. Jakarta: Pustaka Imam Asy-Syafi'i, 2011.

[5] N. Yazdani and M. Lozanovska, "The design philosophy of Edenic gardens: tracing 'Paradise Myth' in landscape architecture," Landscape History, vol. 37, no. 2, pp. 5-18, 2016.

[6] N. A. Baharudin and A. S. Ismail, " Communal Mosques: Design functionality towards the development of sustainability for community," Procedia - Social and Behavioral Sciences, vol. 15, no. 3, pp. 106 - 120, 2014.

[7] [Depag] Departemen Agama RI, "Sistem Informasi Masjid Seluruh Indonesia" [internet]. [download $2018 \quad 12$ September]; Avaible on http:// simas.kemenag.go.id/index.php/ profil/masjid/ tipologi_id, 2014.

[8] S.O. Turan, M. Pulatkanb, D. Beyazlıa, and B. S. Özenc, "User evaluation of the urban park design implementation," Procedia - Social and Behavioral Sciences, vol. 216, pp. 306 - 315, 2016.

[9] M. A. Morisan, Metode Penelitian Survei. Jakarta: Kencana Prenada Media Grup, 2012.

[10] Y. Qardhawi, Islam Bicara Seni, Ahmadi W, translator, Solo: Era Intermedia, 2004.

[11] A. Hilmi, Tashwir: Seni Rupa dalam Pandangan Islam, Jakarta: Rumah Fiqih, 2018.

[12] A. Sarwat, Seri Fiqh Kehidupan (9), Jakarta: DU Publishing, 2011.

[13] E. K. Zavadskas, R. Bausys, and I. Mazonaviciute, "Evaluation Methodology of Urban Public Parks by Multi-criteria Decision Making," Landscape and Urban Planning, vo. 189, pp. 372-381, 2019.

[14] M.N. Ar-Rifa'i, Ringkasan Tafsir Ibnu Katsir Jilid 3. Syihabuddin, translator. Jakarta: Gema Insani, 2000.

[15] M. Asy’ari M, "Islam dan seni," J Hunafa, vol. 4, no. 2, pp. 169-174, 2007. 
[16] A. Setiyawan, "Legitimasi hukum adat ("urf) dalam Islam," J. Esensia, vol. 8, no. 2, pp. 203222, 2012.

[17] Y. Qardhawi, Halal dan Haram dalam Islam, Hamadi HM, translator. Surakarta: Era Intermedia, 2000.

[18] M. Q. Shihab, Wawasan Al-Qur'ān: Tafsir Maudhui, Bandung: Mizan, 1998.

[19] S. S. Y. Lau, Z. Gou, and Y. Liu, "Healthy Campus by Open Space Design: Approaches and Guidelines," Frontiers of Architectural Re- search, vol. 3, pp. 452-467, 2014.

[20] B. Deforche, D. Van Dyck, M. Verloigne, and I. De Bourdeaudhuij, "Perceived Social and Physical Environmental Correlates of Physical Activity in Older Adolescents and The Moderating Effect of Self-Efficacy," Prev. Med., vol. 50, no. 1, pp. 24-29, 2010.

[21] S. Payne, "Open space: people space," J. Environ. Psychol., vol. 29, no. 4, pp. 532-533, 2009. 